\title{
Review
}

\section{Global Future: Low-Carbon Economy or High-Carbon Economy?}

\author{
Diosey Ramon Lugo-Morin (1)
}

check for

updates

Citation: Lugo-Morin, D.R. Global Future: Low-Carbon Economy or High-Carbon Economy?. World 2021, 2, 175-193. https://doi.org/10.3390/ world 2020012

Academic Editor: Manfred Max Bergman

Received: 4 March 2021

Accepted: 8 April 2021

Published: 9 April 2021

Publisher's Note: MDPI stays neutral with regard to jurisdictional claims in published maps and institutional affiliations.
Postgraduate Program in Sustainable Management of Natural Resources, Management of Sociological Systems, Research and Postgraduate Studies, Intercultural University of Puebla State, Huehuetla, Puebla 73475, Mexico; diosey.ramon@uiep.edu.mx

\begin{abstract}
This study critically examines the decarbonization of development in the context of the Anthropocene at the global level. A literature review is conducted that emphasizes the rationality of human beings to harmonize with the planet due to the low capacity of their human agency in the framework of the Anthropocene. The analysis recognizes that the possibility of transitioning to a decarbonized global economy or zero carbon emissions is not encouraging. Global energy production and $\mathrm{CO}_{2}$ emissions are concentrated in a dozen countries: China, United States, Russia, Saudi Arabia, Canada, Iran, India, Australia, Indonesia, and Brazil. These countries are part of societies with an advanced social metabolism that negatively impacts the production of $\mathrm{CO}_{2}$. In context, the COVID-19 pandemic has provided some level of environmental health for the planet, but the $\mathrm{CO}_{2}$ reduction levels are still insufficient to consider a positive impact towards 2030.
\end{abstract}

Keywords: global; carbon; Anthropocene; human agency; rationality

\section{Introduction}

The Anthropocene is known as the geological era caused by the planetary effects of human actions [1-4]. These actions are basically governed by two factors: an increase in the planet's population and consumption [5], both of which are immersed in an atmosphere of connectivity [6-8]. The global connectivity that humans have deployed has not only economic but also cultural, political, environmental, and social effects [7,9-11]. The biosphere is the place where all these elements converge, resulting in an abrupt transformation of the environment $[12,13]$. We are ending the natural resources and resilience of the planet $[14,15]$; it is estimated that if we continue with an accelerated growth rate like the current one for 2050, we will need two planets to face the challenges of a population increase and their consumption [16].

An important factor in these dynamics has been climate change, with the 5th Report of the Intergovernmental Panel on Climate Change (IPCC) pointing to an anthropogenic increase in global average temperature [17]. Recent studies derived from paleoclimate, as the instrumental period, reveal an increase in greenhouse gases since 1900 [18-21]. The natural system as well as anthropogenic actions have played an important role in climate variability, setting appropriate scenarios for the increase in greenhouse gases [22].

The importance of reducing the emission of greenhouse gases on the planet, in particular carbon dioxide $\left(\mathrm{CO}_{2}\right)$, has been well known since the first reports of the Intergovernmental Panel on Climate Change (IPCC). It is debatable whether we think that the use of $\mathrm{CO}_{2}$ is associated with progress or development in a country. Following this logic, would a country like the United States be willing to decrease its $\mathrm{CO}_{2}$ emissions in favour of the environment? If we observe the actions of its president's administration, they are clearly sending signals that the country is not willing to decrease its $\mathrm{CO}_{2}$ emissions [23,24].

It seems that the decarbonization of development can be good for some countries and bad for others $[25,26]$. The world economy is based on a capitalist development model $[27,28]$, a model in which its main premise in obtaining profits in an unlimited way and its main promoter is the United States, which probably would not leave aside such 
model just to save the planet [29]. The alliances that the United States has woven with other countries around the world do not respond to reciprocity or solidarity, they respond to common interests $[30,31]$, and clearly global climate policy does not respond to the interests of the United States [23,32]. During Donald Trump's administration, the US dismantled dozens of environmental and climate policies that impacted vehicle emissions, power plants, and oil-gas infrastructure. Under new US President Joe Biden, the US is expected to turn around its climate policy, starting with reversing and improving the climate rules that his predecessor changed or eliminated [33]. There is global resistance to limiting the global temperature rise to less than $2{ }^{\circ} \mathrm{C}$, but global governance is not giving up hope [34].

Other regions of the planet, such as Latin America, Africa, and Southeast Asia, despite not having energy efficiency policies due to a lack of infrastructure and financing, do not contribute significantly to the increase in $\mathrm{CO}_{2}$ [35], although there is an aspect interrelated to decarbonization, which is the loss of sinks due to the deforestation of vast forested areas. Processed data from two decades ago show that forests globally were carbon sinks of $-7.6 \pm 49 \mathrm{GtCO} 2 \mathrm{e} \mathrm{yr}^{-1}$ [36]. However, the lack of regulatory policies in the context of anthropogenic activities (e.g., deforestation and biomass burning) put this capacity of terrestrial sinks at risk [37]. The outlook for these regions to aim for decarbonization of development is not encouraging.

European Union and its Member States reflect a different reality when considering decarbonising energy supply and improving energy efficiency [38]. Both strategies, rigorously applied, can have a positive impact on reducing $\mathrm{CO}_{2}$ emissions, but their consideration in the framework of an effective energy policy is compromised because they do not take into account the preferences of the people who are the main recipients of these strategies. In this sense, Brugger [38] mention the relevance of new social trends (e.g., digitalisation, collaborative economy, and consumer awareness); but, although these trends look encouraging in an energy efficiency framework, there is still a lot of uncertainty, as the parametric rationality of Europeans is an important variable in energy efficiency.

Within this parametric rationality, the study by Sovacool [39] argues that European citizens have a dependence on fossil fuel-fired heating and cooling services. Within European households, these services are difficult to decarbonise, as the study points out that Europeans' preferences for changing their conventional (fossil fuel) heating and cooling systems are very low, i.e., a decarbonised heating and cooling system is not in the interest of European households.

In the other part of the world, in this case China that seeks to expand its domains with the New Silk Road Project [40], this project poses a geopolitical challenge for the Chinese because its main objective is the re-design of the global connection network through infrastructure: a network of roads, railways, ports, and airports between Asia and Europe [41,42].

The ambitious Chinese proposal had an initial investment of USD 491 billion with various funding sources (e.g., Chinese Development Banks, Silk Road Fund, and the Asian Infrastructure Investment Bank) [43]. Investments for this project are considered until 2040, and currently the COVID-19 pandemic is not a major obstacle in China's plans [44]. The projected investments can be seen in Table 1.

The impact of the COVID-19 pandemic may slow down China's aspirations in the context of new infrastructure. However, China's interest in offshoring excess capacity and expanding abroad, as well as its ability to finance its businesses (e.g., Huawei, ZTE, and Alibaba), may continue to drive this project due to the establishment of technology and infrastructure platforms, architecture, and systems built to Chinese standards. 
Table 1. Comparison of the estimates of global infrastructure investment needs.

\begin{tabular}{|c|c|c|c|c|}
\hline \multirow{2}{*}{ Sectoral Scope } & \multirow{2}{*}{$\begin{array}{c}\text { Actual/Expected Annual } \\
\text { Investment (USD Trillion) [1] }\end{array}$} & \multicolumn{3}{|c|}{ Investment Need (USD Trillion) } \\
\hline & & Time Frame & Total & Per Annum \\
\hline \multirow{3}{*}{$\begin{array}{l}\text { Including power generation, } \\
\text { transmission and distribution, primary } \\
\text { energy supply, energy demand and } \\
\text { efficiency, transport, water and } \\
\text { sanitation, and telecommunication }\end{array}$} & $3.4(2015)$ & $2015-2030$ & $75-86$ & $5-6$ \\
\hline & - & $2015-2030$ & 96 & 6.4 \\
\hline & $3.4-4.4(2017)$ & 2016-2030 & 95 & $\begin{array}{c}6.3 \text { (or } 6.9 \text { under a } \\
2^{\circ} \mathrm{C} \text { scenario) }\end{array}$ \\
\hline $\begin{array}{l}\text { Including roads, railways, airports, } \\
\text { electricity generation, transmission and } \\
\text { distribution, water, } \\
\text { and telecommunication }\end{array}$ & 2.3 (2015) growing to $3.8(2040)$ & 2015-2040 & 94 & $2.9(2015)-4.6(2040)$ \\
\hline $\begin{array}{l}\text { Including transport (roads, railways, } \\
\text { airports, and ports), water, power, } \\
\text { and telecommunication }\end{array}$ & 2.5 & 2016-2030 & 49 & 3.3 \\
\hline
\end{tabular}

The approaches to estimating the actual investment needs and expected investment trends vary widely among studies. Source: [43].

The Silk Road Project is a great project aiming at improving regional cooperation through better connectivity among countries lying on the ancient Silk Road and beyond [45]. It includes the Silk Road Economic Belt for the land part and the 21st Century Maritime Silk Road for the naval part [46]. At the start, it involved 64 economies, but its scope has since broadened to over 100 [43]. Due to the Chinese aspirations broken down above, China moves in a geopolitical scenario that does not offer certainty regarding decarbonization [47]. In the Chinese geopolitical framework, the Silk Road Project, in both its land-based (including Europe and Asia) and maritime (Africa is added) versions, shows a Chinese government distanced from the global policy of decarbonization.

In the nearly 30 years since the adoption of the United Nations Framework Convention on Climate Change (UNFCCC), which committed signatories to prevent "dangerous anthropogenic interference with the climate system", global emissions have continued to rise at a rapid pace: more than half have been emitted since 1990 [48,49] and U.S. emissions have increases. These increases are largely due to the neoliberal shift and the anti-regulatory, anti-public "competitive state" that, although more fully realized in the United States, has global influence [50]. According to Selby [24], even with good mitigation policies or negative-emission technologies [51], i.e., technologies that remove $\mathrm{CO}_{2}$ from the atmosphere and store it underground or in the sea, although currently unproven, it seems likely that warming in the mid to late 21 st century will reach between $2.6^{\circ} \mathrm{C}$ and $3.2^{\circ} \mathrm{C}$.

Under the scenarios described and the deployment of adaptive institutions (AI), the term $\mathrm{AI}$ is associated with the strategic co-optation or subordination to the power deployed by the United States and some emerging powers, such as China and India, in global climate policy $[52,53]$. This study aims to critically analyse the decarbonization of development in the context of the Anthropocene. In order to achieve the stated objective, methodologically the study adopted a qualitative perspective that through an exhaustive literature review allowed an approach to the state of the art on the decarbonization of development in the context of the Anthropocene. The information obtained was systematised and analysed using search categories linked to the Web of Science (WoS). For a better understanding of these categories, a theoretical model was developed.

Based on the model, the review systematised the publications associated with the Anthropocene, decarbonization, global climate policy, human agency, and individual rationality. The wealth of information gathered provided a broad view of decarbonization of development considering national, regional, and global scenarios. In order to better follow the object of study, the paper was structured in the following sections: the scope of the Anthropocene and decarbonisation; the methodology employed; theoretical and conceptual aspects of the Anthropocene; theoretical and conceptual aspects of decarbonization; and findings and discussion and conclusions 


\section{Context and Surrounding the Anthropocene and Decarbonization}

The Anthropocene is the political label designed to draw attention to anthropogenic change at the planetary level and the changing notions of agency and responsibility in contemporary life [51,54]. It emerged as a side effect of the industrialisation of human societies [55]. There are only a few examples of the human capacity to interact internally with planetary geological forces, the Montreal Protocol being the most mentioned example [56]. Achieving the policy challenges as described in the Sustainable Development Goals (SDGs) requires a certain degree of social transformation. The concept of agency is fundamental to implementing the transformations needed to limit global warming and achieve the SDGs [57].

Human agency at the planetary level is an unprecedented challenge. Agency is derived from interactions, negotiations, and social struggles that take place between human beings and institutions. According to Long [58], the notion of agency attributes to individuals the capacity to process social experience and design ways of dealing with life, even under the most extreme forms of coercion. Within the limits of information, uncertainty, and other restrictions, individuals and institutions possess the capacity to know and the ability to act. The execution of human agency is differentiated from all human individuals and social group. According to Otto [57], social institutions for the sustainable management of global, regional, and local ecosystems must be intervened and improved for an efficient use of resources. According to the authors, every social transformation contains a disruptive component that implies a destruction of existing patterns of social interaction and institutional structures and the creation of new ones.

The position of Otto [57] is questionable: the renewal of social institutions in a historical context is a fact, but their dynamic of change does not obey third parties but the very social group that hold them. The idea of this critical review is to explore the potential and challenges of the concept to foster an inclusive understanding of global change within the framework of decarbonization. Under this logic, it is considered that we cannot generate adequate problematizations around decarbonization if we do not see these processes through the lens of a socioecological system.

Since human beings have been on the planet, they have established a close relationship with nature. From those remote times until today, this relationship has evolved into a destructive relationship with nature [14,59]; the ecological footprint of Wackernagel and Williams [60] offers a methodology to confirm this. To speak of a possible reduction in $\mathrm{CO}_{2}$ concentrations is tantamount to saying that humans would be willing to rethink their status quo. The answer is complex, as human society as we know it today would not be willing to change its lifestyle, even when knowing the destructive implications of its social metabolism [61]. For example, in the scenario derived from the effects of the COVID-19 pandemic, we observe that, despite global health measures (e.g., restrictions on spatial mobility, confinement, and border closures), the $\mathrm{CO}_{2}$ levels have not only not been reduced but are steadily increasing [62]. Climatologically speaking, the mitigation effect of the COVID-19 pandemic in the context of global GHG emissions is a drop of $4.5 \%$, which is insignificant for an initial global decarbonisation process [63]. Figure 1 shows the daily global dynamics of $\mathrm{CO}_{2}$.

The pandemic has caused a slowdown of the global economy with negative consequences for the transport and tourism sectors and directly impacting on employment and household income [63]. As of today, 8 April 2021, the level of confirmed cases of the COVID-19 pandemic has increased to 132 million people infected and 2.8 million people dead [64]. Global society in a context of socio-economic vulnerability will be challenged to recover from the effects of the COVID-19 pandemic. Individual parametric rationality will be another challenge to overcome if we are to decarbonise development. Theorising around the status quo, we mention two reflective axes inherent to human beings: their biological condition that leads them to individualism from their cellular replication [65] and their social condition that entrenches selfishness in society [66]. In a process of decarbonization of development, the COVID-19 pandemic has not affected $\mathrm{CO}_{2}$ levels, but has slightly 
impacted the environmental health of the planet [67]. The biggest challenge is man who has driven chaotic and destructive actions that shape nature.

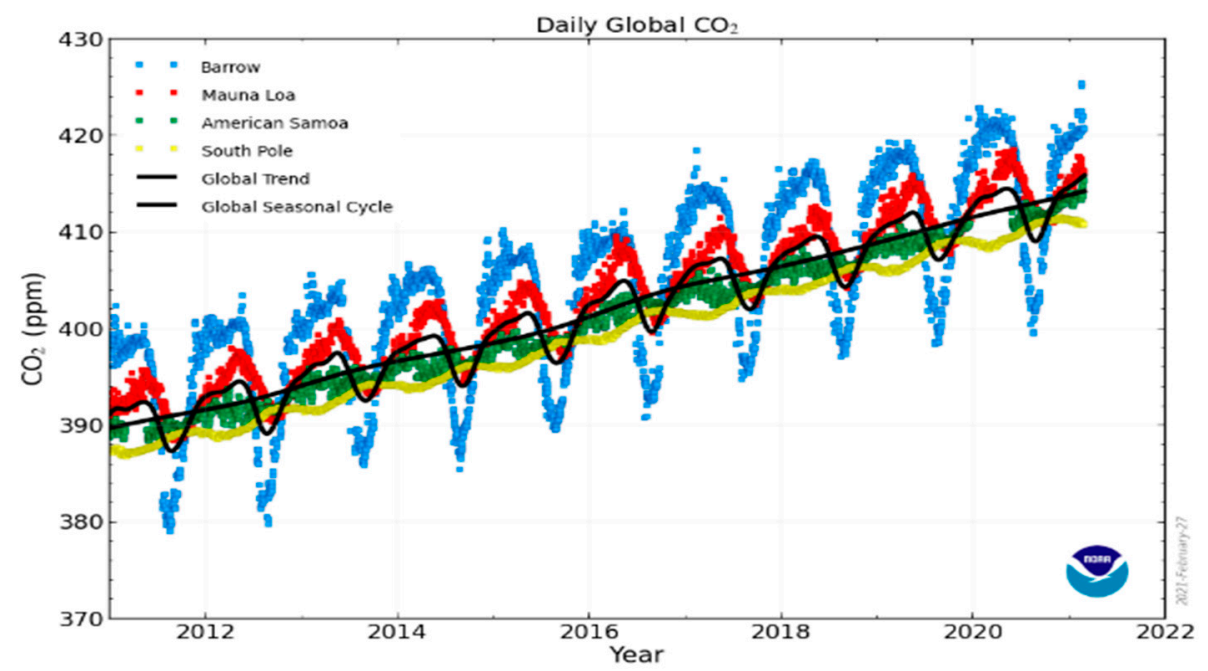

Figure 1. Daily global $\mathrm{CO}_{2}$. Shows daily averaged $\mathrm{CO}_{2}$ from four $\mathrm{GML}$ Baseline observatories; Barrow, Alaska (in blue); Mauna Loa, Hawaii (in red); American Samoa (in green); and South Pole, Antarctica (in yellow). The thick black lines represent the average of the smoothed seasonal curves and the smoothed, de-seasonalized curves for each of the records. These lines are a very good estimate of the global average levels of $\mathrm{CO}_{2}$. Source: [62]. (Available online: https:/ / www.esrl.noaa. gov/gmd/ccgg/trends/gl_trend.html accessed on 1 April 2021).

Based on the previous approaches, decarbonization for development is a utopia in the metabolic conditions of today's society. In this study, we start from the fact that social metabolism is the result of a complex network of exchange, closely linked to transformations, in which the old, direct, and almost immediate relationship between appropriation and consumption is blurred [68,69]. For most of human history, energy use by humans was but a tiny fraction of the overall energy input into the biosphere. However, the industrial revolution gave humans the capacity to push energy inputs towards planetary scales and by the end of the 20th century human energy use had reached a magnitude comparable to the biosphere [70]. An empirical study points out how individualism in human being prevails in the pursuit of their interest, e.g., a topic such as international trade could be of interest only if it obtains a benefit [71]. Following the same logic, we can mention nature or climate change [72-74].

Paramio [75] reminds us that people tend to behave not in a completely arbitrary way, or in a way simply moved by feeling, but rather they tend to develop strategies to maximize their interest, strategies to achieve the satisfaction of their interest as much as possible according to the resources with which they start beforehand. Although other models of rationality are not unknown [76], today's global society is generating fickle individuals, dynamic in their own identity and culture, simultaneously adopting different rationalities [77]. This multi-rationality of the individual is being configured due to a complex system of preference calculations based on the social metabolism of today's global society.

\section{Methods}

To achieve the objective of critically examining the implications of decarbonization of development in the context of the Anthropocene, a qualitative perspective was adopted, and an extensive literature review provided an important insight into the state of the art of the object of study. A total of 200 publications were collected, mostly scientific articles and to a lesser extent official reports from international organisations $[43,62,78-80]$. The search was conducted from June 2020 to February 2021. 
The first compilation examined the following central themes: Anthropocene, Decarbonization, Global Climate Policy, Human Agency, and Individual Rationality. The systematisation and analysis of the information allowed a more refined search to be carried out, finally selecting 144 publications; the studies selected not only referred to the central themes mentioned above but were extended to other topics as well, such as Capitalism and the Environment, Social Metabolism, and Energy Production.

\subsection{Design of the Literature Review}

The systematic literature review was based on a search for the keywords Anthropocene*, Decarbonization*, Global Climate Policy*, Human Agency*, Individual Rationality*, Capitalism and Environment*, Social Metabolism*, and Energy Production*. The search was conducted through the Web of Science (WoS). The construction of a theoretical model of the study facilitated the choice of keywords that led to the first immersion: 200 publications were collected, which were further refined to 144 papers that supported the central idea of the present study.

The theoretical model traces a line of the Anthropocene, which we address from its origin to the present day. In this period, the Anthropocene has had a major impact on the biosphere, and among the elements that stand out was the presence of greenhouse gases, in particular $\mathrm{CO}_{2}$; its analysis involved considering multiple interactions (e.g., social, environmental, political, and economic) at national, regional, and global scales. From this perspective, this gas $\left(\mathrm{CO}_{2}\right)$ has constituted a shaping element for the planet, and the analysis allowed us to understand its impact, its origin, production, and how humanity has perceived it. Global climate policy, human agency, and the rational logic of the individual are shaping elements. We believe that this in-focus approach will allow us to recognise in a preliminary analysis the effects of $\mathrm{CO}_{2}$ on development. Figure 2 shows the theoretical model used in the framework of the literature review.

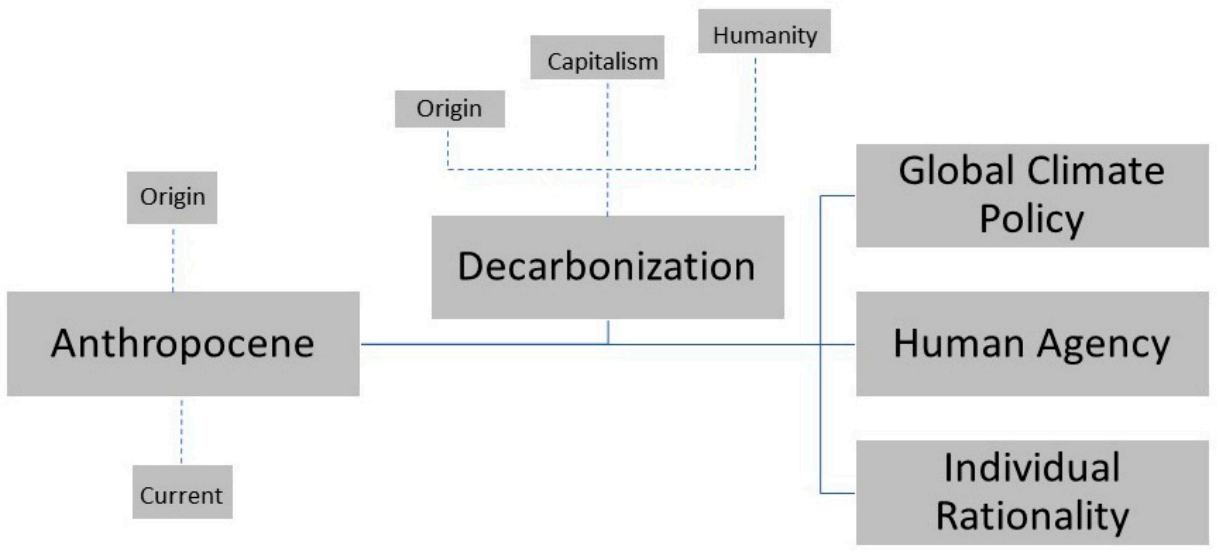

Figure 2. Theoretical model used for the study.

\subsection{Categories and Criteria of the Systematic Review}

The review brought us closer to the state of the art of the central themes identified in the theoretical model of the study. We were able to establish categories of analysis ranging from global events that affected the dynamics of the earth system and its climate to events with smaller scopes, represented in the greenhouse gases and the gas that configures this family of gases: $\mathrm{CO}_{2}$. The criteria for the systematic review were based on scientific articles and official reports, resulting in a highly refined and descriptive exploration. In order to avoid documents of dubious provenance, grey literature was not considered and excluded from any analysis.

\section{Some Elements to Understand the Anthropocene}

According to Anthropocene Working Group (AWG), the Anthropocene is to be stratigraphically real, and recommends formalization at the epoch/series rank based on a 
mid-20th century boundary. Currently, progress is being made on indicators that establish a global correlation in a wide variety of sedimentary bodies, both marine and non-marine [81]. For example, the environmental changes associated with well-mixed atmosphere gases provide clearly global synchronous geological makers on an annual or decadal scale, as required to define the Global Stratigraphic Standard Age (GSSP) for the Anthropocene. The earliest potential GSSP primary marker they identified is atmospheric methane inflection at 5.020 years, but the correlated auxiliary stratotypes are missing [82].

Everything seems to indicate that there are two probable dates for the beginning of the Anthropocene. According to Lewis and Maslin [82], the probable dates of the beginning of the Anthropocene are 1610 (Orbis Spike) or 1964 (Bomb Spike). Choosing the Orbis spike (1610) implies that colonialism, world trade, and coal caused the Anthropocene. Overall, this highlights social concerns, particularly the unequal power relations between different groups of people, economic growth, the impacts of globalized trade and our current dependence on fossil fuels. The aftermath of the arrival of Europeans in the Americas also highlights a long-term, large-scale example of human actions triggering processes that are difficult to predict or manage. Choosing the bomb spike (1964) tells the story of elite-driven technological development that threatens the destruction of the planet. The long-term advance of technology deployed to kill people, from spears to nuclear weapons, highlights the broader problem of "progress traps". The 1963 Partial Test Ban Treaty and subsequent agreements highlights the ability of people to successfully collectively manage a major global threat to humans and the environment.

According to Gillings and Paulsen [83], the human influences on the planet's atmosphere, hydrosphere, and biosphere are of such magnitude that they justify naming a new geological epoch, the Anthropocene. Different dates and starting phases have been proposed for this epoch, depending on the criteria used. Recent advances in microbial genomics and ecology show that human disturbances in microbial populations correspond closely to the proposed phases of the Anthropocene: the "Palaeoanthropocene" that began with the emergence of agriculture, the Industrial Revolution of the late 1700s, and the "Great Acceleration" from the 1950s to the present.

The concept encapsulates the new and unprecedented changes on a planetary scale resulting from social transformations and has revealed the social drivers of global change, revealing tensions between widespread interpretations of humanity's contribution to global change and historically, politically, and culturally situated interpretations [84].

\subsection{Current}

The Anthropocene is a component of a system where social component interactions marked this era. A system is a set of components that interact with each other within defined limits. The earth system is a complex socioecological system that includes a vast set of interacting physical, chemical, biological, and social components and processes that determine the state and evolution of the planet and of life on it [80]. Figure 3 shows the dynamics of GHGs in the composition of the atmosphere.

The components of the earth system are the atmosphere, biosphere, hydrosphere, and geosphere. These provide the environmental processes that regulate the functioning of the earth, such as the case of the climate system, the ecological services generated by the living biosphere, including food production, and natural resources such as fossil and minerals. The complexity of the earth system is associated with a number of interacting processes at different scales and levels of organization of this system [7]. Humans are an integral component; their interaction with the atmosphere, biosphere, hydrosphere, and geosphere generates adaptive processes, transformation, and uncertainty. Table 2 shows how the interactions between the different components of the earth system are being affected by anthropogenic activities. 


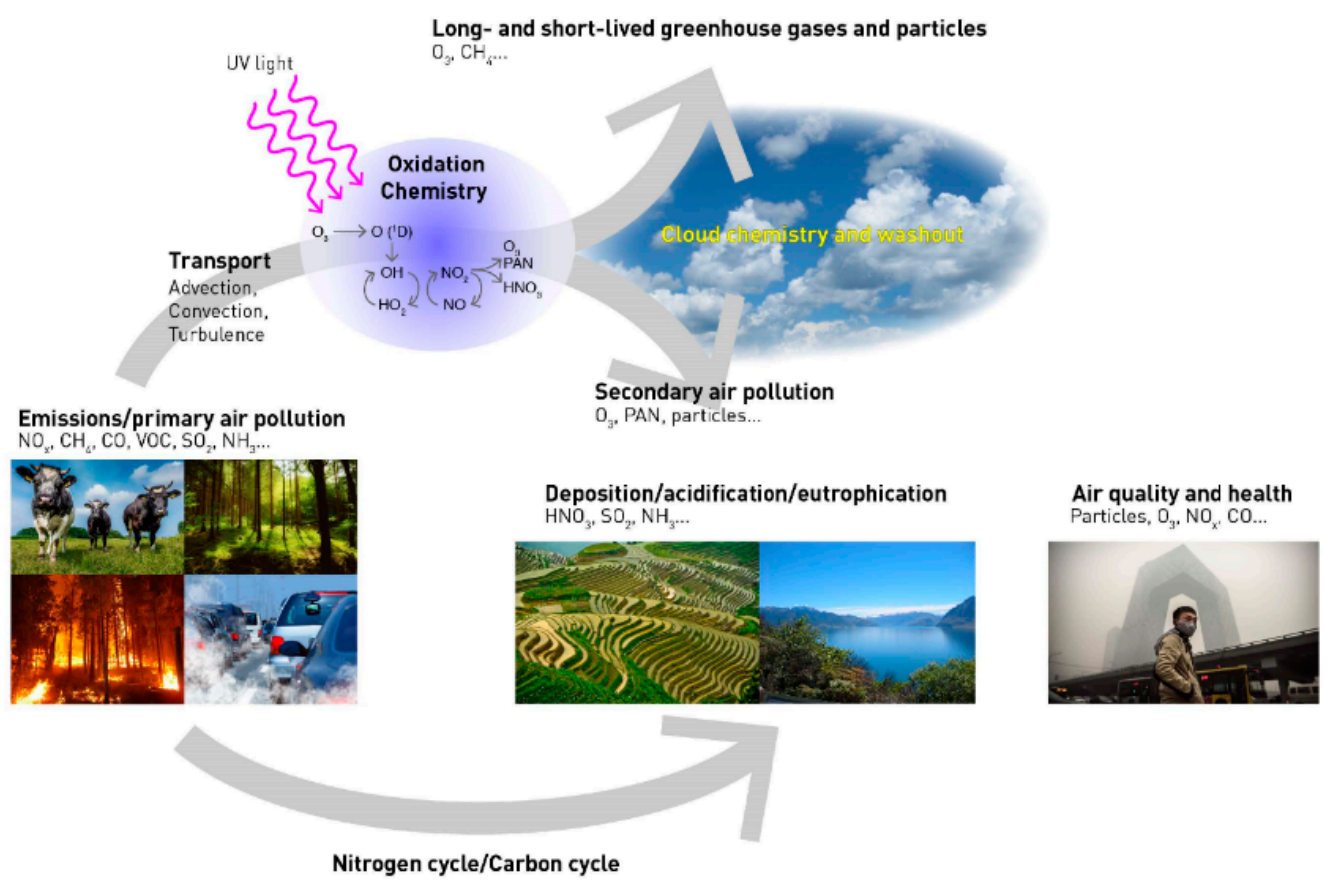

Figure 3. Dynamics of the composition of the atmosphere. Source: [78]. Global Atmosphere Watch Programme (GAW). Available online: https:/ / community.wmo.int/activity-areas/gaw, accessed on 1 April 2021.

Table 2. Interactions in the earth system that are affected by human activities.

\begin{tabular}{|c|c|c|}
\hline Interaction & Human Activities & Levels of Impact \\
\hline $\begin{array}{l}\text { Atmosphere- } \\
\text { Biosphere }\end{array}$ & $\begin{array}{l}\text { - Alterations in the atmosphere concentrations of } \\
\text { sulphur dioxide affect terrestrial and freshwater } \\
\text { ecosystems through acid rain, which has an impact in } \\
\text { terms of aquatic species, as well as on biodiversity and } \\
\text { forests. } \\
\text { The biosphere in the polar regions suffered pollution } \\
\text { from the long-distance transport of industrial } \\
\text { pollutants produced on other continents. }\end{array}$ & $\begin{array}{l}\text { Local, regional, } \\
\text { and global }\end{array}$ \\
\hline
\end{tabular}

- $\quad$ Underground aquifers are being depleted, which can lead to subsidence of the land and intrusion of saline

Geospherewater into freshwater reservoirs. Furthermore, due to Hydrosphere human activities such as agriculture, nutrient mobilization in watersheds around the world,

Global including phosphorus and nitrogen, has increased significantly since 1960.

- Global permafrost temperatures have been rising for half a century, releasing $\mathrm{CO}_{2}$, nitrous oxide $\left(\mathrm{N}_{2} \mathrm{O}\right)$ and methane $\left(\mathrm{CH}_{4}\right)$ into the atmosphere, accelerating

Atmosphereglobal warming.

Geosphere

- The frequency of rainfall in the world has increased (floods and droughts). Long-term projections show a

Global and regional trend towards drier conditions in the Sahel and northern India. 
Table 2. Cont.

\begin{tabular}{llll}
\hline Interaction & \multicolumn{1}{c}{ Human Activities } & Levels of Impact \\
\hline $\begin{array}{c}\text { Biosphere- } \\
\text { Hydrosphere }\end{array}$ & $\begin{array}{l}\text { The construction of dams and the control of rivers and } \\
\text { their flood plains affect both systems and biodiversity. }\end{array}$ & $\begin{array}{l}\text { Water pollutants from industrial effluent waste } \\
\text { disposal, drainage water, solid waste, agricultural } \\
\text { runoff, and air pollution (acid rain) represent a major } \\
\text { threat to wetlands and their biodiversity. }\end{array}$ & $\begin{array}{c}\text { Local, regional, } \\
\text { and global }\end{array}$ \\
\hline $\begin{array}{l}\text { Atmosphere- } \\
\text { Hydrosphere }\end{array}$ & $\begin{array}{l}\text { A significant portion of anthropogenic } \mathrm{CO}_{2} \text { emissions } \\
\text { is absorbed by the oceans each year. This } \mathrm{CO}_{2} \text { reacts } \\
\text { with water to form carbonic acid, which increases the } \\
\text { acidity of seawater. } \\
\text { Some persistent chemicals, such as persistent organic } \\
\text { pollutants and heavy metals, reach the marine } \\
\text { environment and are transported globally, causing } \\
\text { toxic effects on humans and wildlife. }\end{array}$ & Global \\
\hline $\begin{array}{l}\text { Geosphere- } \\
\text { Biosphere }\end{array}$ & $\begin{array}{l}\text { Oil spills are a threat to aquatic and marine } \\
\text { ecosystems. }\end{array}$ & Global and \\
\hline
\end{tabular}

Sources: Own elaboration based on data from [80,85-91].

The increase in the world's population and its consumption patterns have been catalysts for the global changes the planet is experiencing today [5]. These changes are observable at the global level and are characterized by deforestation of forests [92], intensive use of agro-pollution [93], loss of biodiversity [94], loss of local knowledge [95], conflicts and wars [96], use of fossil fuels [97], and changes in land use [98]. The stamp of the Anthropocene at present shows us a global environmental crisis characterized by the changes previously mentioned, a globalized world being permeated by a market logic that subsumes the natural world, and a global society that is governed by a parametric rationality [99].

\subsection{Prospective}

Along with the broad scope of its interdisciplinary dissemination, the Anthropocene has engendered multiple narratives of global change and the future [100]. At least in part, attention to human agency has shifted from the often-catastrophic narratives of global environmental change to new narratives of empowerment and action, through the realization that societies are now globally interdependent to become a major influence on the earth system. The notion of the Anthropocene clearly indicates that both individuals and societies have become increasingly connected in various ways, despite the very unequal contributions and benefits of earth system transformations [84]. Recent publications have proposed a variety of typologies of narratives to represent, and in some cases standardize, the diversity of approaches and voices around the concept of the Anthropocene [84]. Bonneuil's proposal [101] offers a broad perspective, which is listed in Table 3 below.

Table 3. Types of narratives around the Anthropocene.

\begin{tabular}{cl}
\hline Narrative & \multicolumn{1}{c}{ Focus } \\
\hline Naturalist & $\begin{array}{l}\text { Emphasizes what, how, and when humans have altered the earth system, with } \\
\text { particular attention to the potential of interdisciplinary integration to provide } \\
\text { scientific and technological knowledge to society and policy makers with respect } \\
\text { to adaptation and mitigation of the impacts of global change. }\end{array}$ \\
\hline
\end{tabular}


Table 3. Cont.

\begin{tabular}{cl}
\hline Narrative & \multicolumn{1}{c}{ Focus } \\
\hline Post-nature & $\begin{array}{l}\text { It deploys the term Anthropocene as a symbol of post-modernity, where the } \\
\text { dichotomy between culture and nature is dissolved, and where the concept of } \\
\text { the Anthropocene is seen as a useful alternative, even if it conveys multiple and } \\
\text { sometimes unclear meanings to go beyond the upheavals of modernity. }\end{array}$ \\
\hline Eco- & $\begin{array}{l}\text { It focuses on the vulnerabilities of society and the dangers of unknown social } \\
\text { and environmental tipping points, highlighting historical studies of } \\
\text { civilizational collapses, narratives and interpretations of crises, limits to } \\
\text { development, and the debate on population }\end{array}$ \\
\hline Eco-Marxist & $\begin{array}{l}\text { It focuses on the contradictions of capitalism in promoting growth, life quality, } \\
\text { and technological advances, while causing environmental disasters. The } \\
\text { emphasis is on the development of the social metabolism from a historical } \\
\text { perspective and its role in unequal global social relations }\end{array}$ \\
\hline Sources: Own elaboration based on data from [5,7,101-108].
\end{tabular}

The last narrative called "eco-Marxist" shows the contradictions of a model that does not change its market logic and at the same time promotes a welfare economy with sustainability criteria. With his critique of capitalist development, Marx [109] showed that the productive forces of mechanised industry generated advances in the productivity of labour, which translated into an increase in the processing of matter and energy. A new interpretation of Marxist theory in the ecological context is likely to show that Marxism provides signals for understanding how the current social metabolism generates crises in the natural conditions of human development.

The idea that the market economy would lead to better standards of living, through the combination of growth and social welfare policies that could reconcile the arrangement of conflicting interests, is challenged by the polarisation between rich and poor nations [110], as the improvement of the quality of life has not been equally distributed [111]. Ethnic and cultural diversity constitutes a "threat" to liberal democracy [112].

From the perspective of political ecology, the notion of ecological distribution is a concept that seeks to integrate the question of the distribution of not only economic but also natural wealth within a sustainable development project. The theory of regulation [113] takes up this concept, considering present and future generations, in the sense that social aspects refer to access to natural resources and the spatial distribution of environmental pollution, supporting the analysis of environmental conflicts and political activity that could find new solutions if it manages to integrate ecological issues and the defence of quality of life. There is a concern in the eco-Marxist position about the waste of natural raw materials and waste [109], where the historical processes of capital determine the need for exploitation of labour power and appropriation of natural resources; this cannot be explained simply as an exchange between culture and its environment, as the human being is part of the biosphere. From this perspective, we see a complex socio-ecological system, reaching a level of comprehensibility of this narrative and applying "the how" will need new analytical tools. In this sense, the authors in [114] provide an analytical alternative.

\section{Decarbonization}

By decarbonization we will understand the process of reducing anthropogenic $\mathrm{CO}_{2}$ to zero carbon. The global concentration of $\mathrm{CO}_{2}$ in the atmosphere has increased from approximately 280 parts per million (ppm) in the late 18th century to over $414 \mathrm{ppm}$ of $\mathrm{CO}_{2}$ in 2021 [62]. The concentration is increasing at a rate of about $2 \mathrm{ppm}$ per year and is not yet showing signs of decreasing. The IPCC [115] has indicated that an atmospheric $\mathrm{CO}_{2}$ concentration of $450 \mathrm{ppm}$ leads to a $2{ }^{\circ} \mathrm{C}$ increase in global temperature from pre-industrial levels and that this should not be exceeded in order to avoid the dangerous consequences of global climate change [115].

As $\mathrm{CO}_{2}$ levels in the atmosphere continue to rise, the likelihood of severe, widespread, and irreversible impacts increases. This was recognized by the United Nations Framework 
Convention on Climate Change, which facilitated the Paris Agreement on Climate Change in which countries promised to reduce emissions. Consequently, it is increasingly likely that some form of $\mathrm{CO}_{2}$ removal will be required to avoid the negative impact of climate change [116].

Climate policy has moved slowly. This frustrates many, whether on the side of those who advocate rapid emission reductions or the view that climate policy is just rhetoric, others argue that climate policy exists to change everything and in the end change nothing, otherwise climate summits and meetings in the last decade would have had an effect on $\mathrm{CO}_{2}$ reduction [117]. For those who still think that climate policies are not "change everything to change nothing", they can look at the monthly measurements made by NOAA [62].

Since 2010, there has been a loosening of global climate policies, although the United States did not show much interest in such policies, at which time Republicans in Congress issued statements mentioning their opposition to climate change action [118]. In 2015, the urgency for global climate policies was recognised and the countries of the United Nations Framework Convention on Climate Change (UNFCCC) agreed to keep global temperatures below $2{ }^{\circ} \mathrm{C}$ and to pursue efforts to limit warming to $1.5{ }^{\circ} \mathrm{C}$ in the Paris Agreement. Consequently, policy makers face the challenge of developing mitigation strategies [119]. Currently, global climate policy has focused on the design of sectoral climate policies, thus giving rise to concepts such as carbon budgeting or geological carbon (geologically sequestering an amount of carbon corresponding to the amount of carbon extracted from the geosphere) [120].

\section{Background and Human Agency in the Scope of Global $\mathrm{CO}_{2}$ Emissions}

Against this background, two major concerns mobilized humanity, and global governance played a strategic role with the achievement of two global mechanisms, the Montreal and Kyoto protocols. The history of chlorofluorocarbons (CFCs) was reminiscent of the battle for dichloro-diphenyl-trichloroethane (DDT) two decades earlier. Like DDT, CFCs were seen as miracle compounds, supposedly inert and harmless molecules with many useful industrial applications. These compounds made household refrigerators and air conditioning safe and reliable, enabled the production of foam products for cushions, food packaging, and insulation, and increased the efficiency of aerosol cans [121].

However, science revealed an unexpected chemical reactivity of these molecules under the high UV conditions of the stratosphere, while satellite observations provided compelling visual evidence of their impact on the Earth's atmosphere [122,123]. In the face of significant opposition and criticism of scientific uncertainty, Molina and Rowland [122] became the leading public voices in the global effort to ban CFCs. Their efforts finally bore fruit in 1987 with the signing of the Montreal Protocol [56]. The Montreal Protocol, ratified by all nations on Earth, charted a path to eliminate the production and consumption of ozone-depleting substances [124]. To this day, it is widely seen as a success story of international cooperation and global policy driven by sound science.

Despite all its success, the Montreal Protocol did not have the expected impact [125]. The CFC problem was seen as a problem of the world's rich nations, and the negotiations were difficult and lengthy. Developing countries had contributed very little to the accumulation of atmospheric CFCs and had legitimate needs to expand the use of these compounds for refrigeration [126].

To address this division, the authors of the Montreal Protocol adopted a novel principle of "common but differentiated responsibilities", which recognized the unequal burdens of responsibilities between industrialized and developing countries [56]: rich industrialized nations would immediately begin reducing CFC use to 50 percent, while developing countries could increase their use by 15 percent. The agreed measures would benefit developing nations, but corruption under the protocol led to a breakdown in CFC consumption [127]. A second concern at the global level was the increase in $\mathrm{CO}_{2}$; once again, world governance 
was coordinated and, at the end of the 1990s, the Kyoto Protocol was agreed upon, which would come into force in 2005.

Since developed economies are the largest emitters and, since industrialisation, have been the main cause of the accumulation of GHG emissions, the protocol places a heavier burden on developed economies in the principle of "common but differentiated responsibilities" [128]. Furthermore, developed countries are expected to provide additional financial resources to advance the implementation of developing countries' commitments [129].

Theorizing about GHG environments, we have two problems: on the one hand, anthropogenic GHGs still constitute a threat despite the efforts of global governance (Montreal Protocol and Kyoto Protocol). On the other hand, natural GHGs are out of control due to global warming, increasing $\mathrm{N}_{2} \mathrm{O}$ and $\mathrm{CH}_{4}$ emissions due to permafrost, biomass burning, livestock activity, and poorly regulated industrial processes in developing countries.

The problems mentioned are deepened when we include the most important of the GHGs, $\mathrm{CO}_{2}$, which is responsible for 70 percent of the GHG emissions. On the anthropogenic side, this gas is produced by the combustion of oil, natural gas, coal, and a wide variety of fossil agents. On the natural side, this gas is produced by permafrost and ocean dynamics. Figure 4 shows the global impact that $\mathrm{CO}_{2}$ emissions have had on the world.

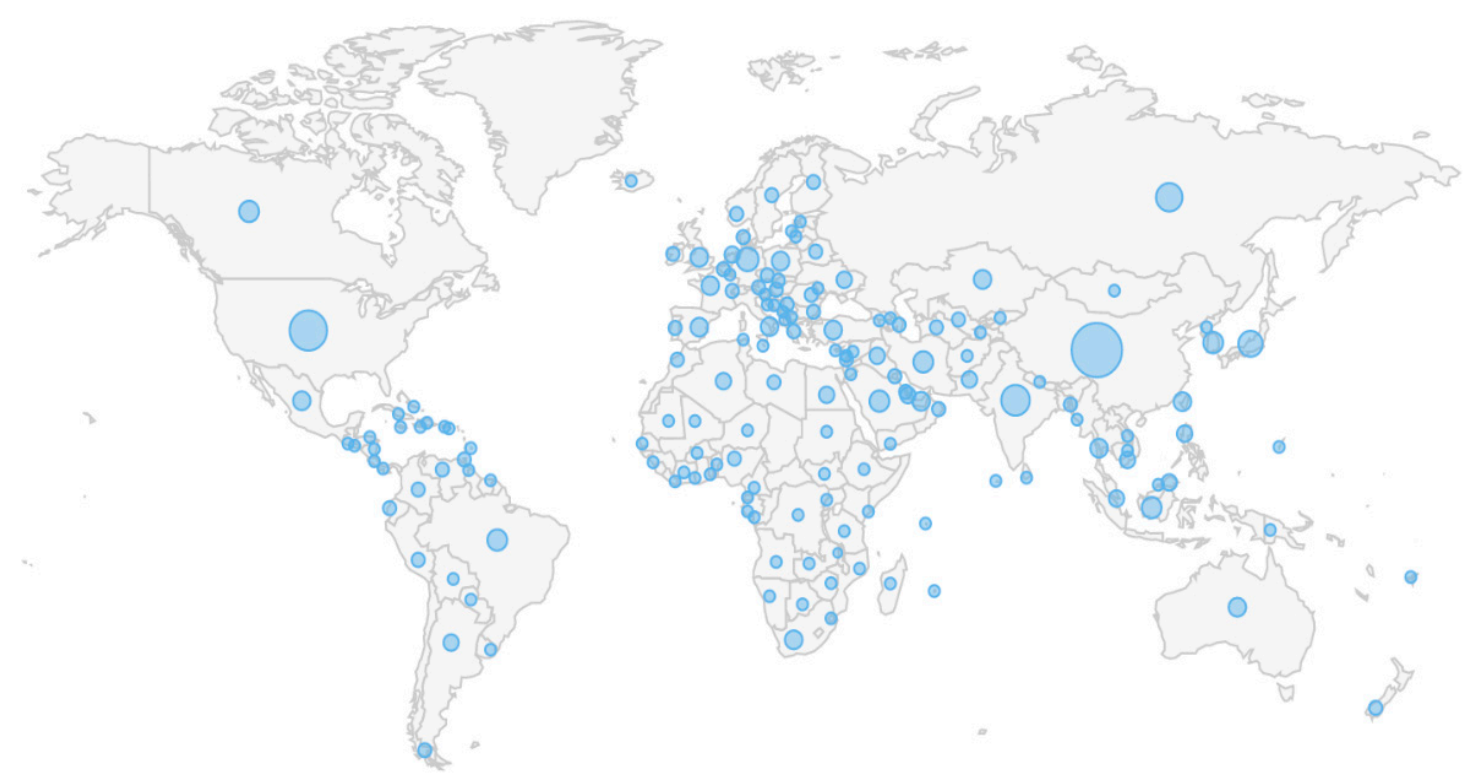

Figure 4. Global $\mathrm{CO}_{2}$ emissions, 1980-2017. Source: [79]. Atmospheric Carbon Dioxide. Available online: https://www.eia. gov/international/data/world/other-statistics accessed on 10 December 2020.

Although we control 45 percent of anthropogenic $\mathrm{CO}_{2}$ [130], the other 55 percent can still affect the Earth System (consequences of the social metabolism of global society). If we add natural $\mathrm{CO}_{2}$, the future scenario is catastrophic [51]. The National Oceanic and Atmospheric Administration points out that terrestrial plants and the global ocean absorb an amount of $\mathrm{CO}_{2}$ equivalent to about half of the 40 billion tons of $\mathrm{CO}_{2}$ pollution emitted by humans each year, and the rate of increase of $\mathrm{CO}_{2}$ in the atmosphere has been steadily accelerating. In the 1960s, annual growth averaged about $0.8 \mathrm{ppm}$ per year. It doubled to $1.6 \mathrm{ppm}$ per year in the $1980 \mathrm{~s}$ and remained stable at $1.5 \mathrm{ppm}$ per year in the $1990 \mathrm{~s}$. The average growth rate again increased to $2.0 \mathrm{ppm}$ per year in the 2000s and increased to $2.4 \mathrm{ppm}$ per year over the last decade. Stabilizing climate change means reducing $\mathrm{CO}_{2}$ emissions to zero. $\mathrm{CO}_{2}$ stays in the atmosphere for hundreds, if not thousands, of years [62]. As long as we emit more than nature can absorb in its sinks (oceans and forests), $\mathrm{CO}_{2}$ concentrations in the atmosphere will continue to rise, influencing global warming. The role of the most industrialized countries is fundamental, which are led by China, United States, and Russia. Figure 5 shows how in the last four decades the economies of China, 
United States, Russia, Saudi Arabia, Canada, Iran, India, Australia, Indonesia, and Brazil have contributed to the increase in $\mathrm{CO}_{2}$.

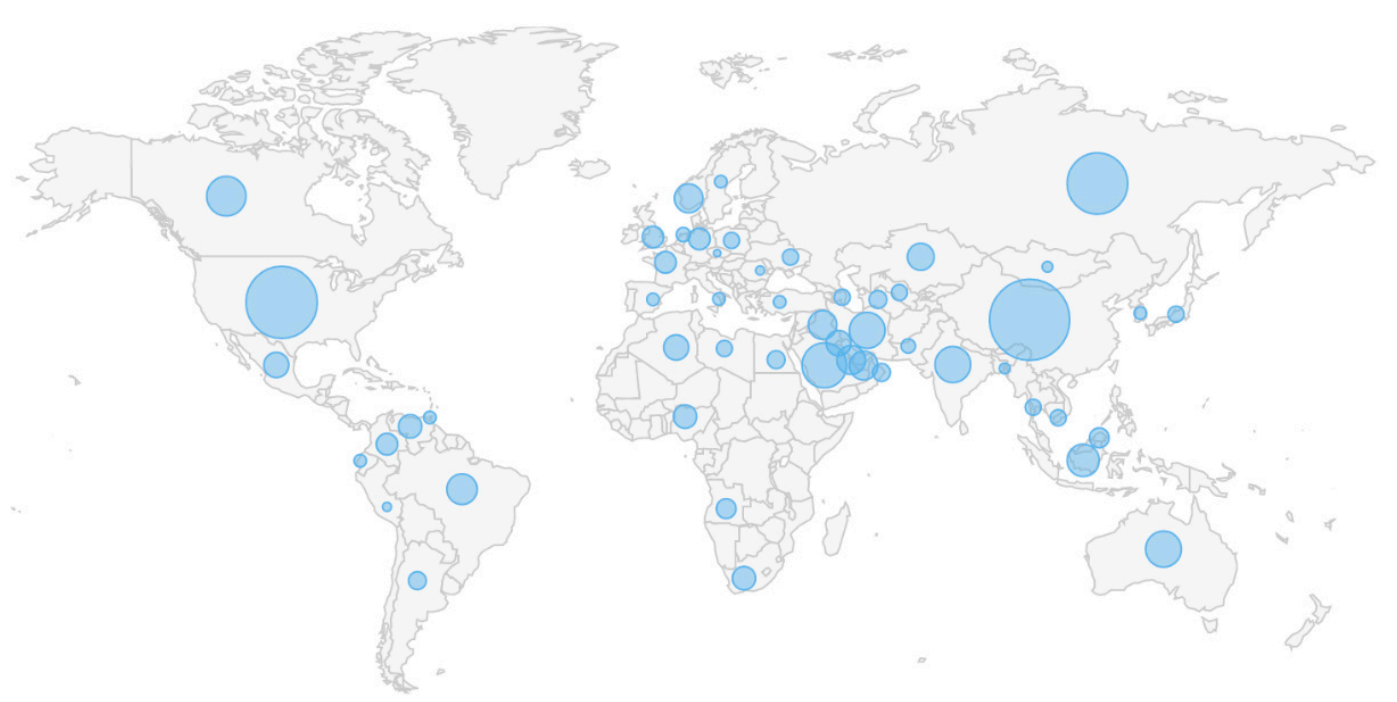

Figure 5. Total energy production, 1980-2017. Source: [79]. Global energy production. Available online: https://www.eia. gov/international/data/world/other-statistics accessed on 10 December 2020.

Pertinent large-scale systemic characteristics and relevant regional ramifications of the material social metabolism are still poorly understood, e.g., the structure and dynamic of complex global material supply chains, path-dependency, and potential lock-in created by the different components of the manufactured capital; quantitative assessments of the technical and economic potential to close materials' cycles; or an effective means to balance the huge number of newly introduced chemicals with feasible tools to assess their toxicity for humans and other species [70].

\section{Finding and Discussion}

The results of the review's analysis lead us to identify an economic logic that contrasts with the green vision that organizations such as the UN are trying to show, one example being Agenda 2030. Human activities, the use and production of energy through fossil resources, have negatively impacted the atmosphere with GHG; they have the property of absorbing and re-emitting radiation, returning it to the earth's surface, causing the increase in the temperature of the planet, a phenomenon called the Greenhouse Effect.

GHGs have been present on the planet since its formation, and since the beginning of the Anthropocene the concentrations of GHGs began to change. If we start from this logic, we divide GHGs into anthropogenic (gases produced by human activities) and natural (gases produced by natural systems). The origin of the earth's atmosphere is a profound question of comparative planetology. The basic alternatives are a primary atmosphere captured from the solar nebula or a secondary degassed atmosphere of condensed materials accumulated by the earth. The debate seems resolved in favour of secondary atmospheres, as primary atmospheres probably existed and may have had a minor role to play [131].

Scientists believe that the earth was formed about 4.5 billion years ago [132-134]. In the first 400 million years, a dense atmosphere emerged from the steam and gases expelled during volcanic degasification of the planet's interior [135]. These gases probably consisted of hydrogen $\left(\mathrm{H}_{2}\right)$, water vapour, $\mathrm{CH}_{4}$, and $\mathrm{CO}_{2}$. Before 3.5 billion years ago, the atmosphere probably consisted of $\mathrm{CO}_{2}$, water $\left(\mathrm{H}_{2} \mathrm{O}\right)$, nitrogen $\left(\mathrm{N}_{2}\right)$, and $\mathrm{H}_{2}[131,136-138]$. The most important feature of the ancient atmosphere was the absence of free oxygen. The evidence for an oxygen-free atmosphere is hidden in early rock formations containing many elements, such as iron and uranium [139]. The GHG dynamics has been historically 
relevant, the alteration of natural systems due to anthropogenic activities shows new configurations around $\mathrm{CO}_{2}$.

This has shown that $\mathrm{CO}_{2}$ emissions have been constant since the formation of the earth: before 1900 its emission levels were constant, after that date its levels increased progressively [18]. In this analysis, the causes linked to anthropogenic actions were addressed. Aspects such as individual rationality [75] and social metabolism [57,61] were pillars for arguing the low chances of achieving a decarbonization of global development. Some see the possibility of their countries decarbonising their economies before 2030, the Italian case being one of them [140]. From a broader perspective, the solutions for decarbonization are diverse: financing through a global decarbonization bond [141]; a change of approach through new energy models [142]; the implementation of emission negative technologies [143]; or a return to decent living standards, i.e., drastically lowering energy consumption [144].

The solutions previously put forward amount to proposing utopian narratives. I mention this because on the one hand we have the Global North that does not want to give up its preferences (parametric rationality and social metabolism), and on the other hand, the Global South where the majority of the population is poor and the implementation of energy policies is a complex issue due to a lack of infrastructure and financing. From the eco-Marxist narrative $[101,109,110]$, we perceive how the historical processes of capital determine the need for the exploitation of labour power and the appropriation of natural resources. If these processes define and shape individual and collective human action, we cannot expect good climate policies for a real decarbonization of development.

\section{Conclusions}

The results of the analysis carried out indicate that the possibility of transitioning towards a decarbonization of the global economy or low-carbon emissions in the context of the Anthropocene is not encouraging. Both anthropogenic $\mathrm{CO}_{2}$ and natural $\mathrm{CO}_{2}$ promise an increase due to human agency. Human agency is affecting the resilience processes of natural resources and the sustained increase in $\mathrm{CO}_{2}$ is proof of this. The natural resources are finite, and when we are on the threshold of exhaustion, the human being will see their existence threatened because another world will no longer be possible. The initiation of a global decarbonization process should consider the mitigation of approximately 20 billion tons of $\mathrm{CO}_{2}$ pollution emitted by humans each year. To this end, two global response strategies should be considered: The first is to avoid deforestation and promote agro-ecological agriculture, as well as designing sustainable strategies for livestock activity. These measures could give sustainability to land systems by ensuring the existence of carbon sinks based on land use. The second would be a major global agreement that would initiate a slowdown in the social metabolism of global society. Reducing the flow of materials and energy following the logic of capital would be an unprecedented step for our humanity.

Global governance also has its share of responsibility in the decarbonization of the global economy, the scenario of international cooperation being a fundamental element. Global energy production and $\mathrm{CO}_{2}$ emissions are concentrated in a dozen countries: China, United States, Russia, Saudi Arabia, Canada, Iran, India, Australia, Indonesia, and Brazil. These countries are part of societies with an advanced social metabolism that impacts the production of $\mathrm{CO}_{2}$

China's attempts to extend its influence on Europe, Asia, and Africa through the New Silk Road Project is an unmistakable precedent for the lack of political will to decarbonize development. China's plans are to re-design the global connection network. It is about infrastructure: a network of roads, railways, ports, and airports between Asia and Europe. On the other hand, the poor cooperation of the United States in global climate policy is a sign that this country does not want a decarbonization of its economy. In a post-pandemic context, the needs of emerging powers such as China and India should not go unnoticed. China, despite being the epicentre of the COVID-19 pandemic, remains keen to offshore 
excess capacity and expand abroad. India intends to meet its domestic energy needs to promote the development of its vulnerable territories. The cases of the United States or Europe may see changes according to their adaptive institutionality. The United States is expected to take the lead in global climate policy under the presidency of Joe Biden. Europe's case responds more to the preferences of its citizens than to adaptive institutionality. These scenarios allow us to see both sides of the same coin: the social metabolism of the global society that is not willing to leave its status quo and the little political will of global governance to mitigate global warming and expand the use of sustainable energy due to the geopolitical position of some countries. The COVID-19 pandemic has provided some level of environmental health for the planet, but $\mathrm{CO}_{2}$ reduction levels are still insufficient to consider a positive impact towards 2030. In a less broad context, we see that the pandemic has taught us how the environment greatly influences our social life, but even so, preferences and interests play an important role in society's lifestyle.

Funding: This research received no external funding.

Institutional Review Board Statement: Not applicable.

Informed Consent Statement: Not applicable.

Data Availability Statement: All data and materials have been presented in the paper. Figures shown in the study are either data based or publicly available.

Conflicts of Interest: The author declares no conflict of interest.

\section{References}

1. Malhi, Y. El concept of the Anthropocene. Annu. Rev. Environ. Resour. 2017, 42, 77-104. [CrossRef]

2. Steffen, W.; Crutzen, P.; McNeill, J. The anthropocene: Are humans now overwhelming the great forces of nature. Ambio 2007, 36, 614-621.

3. Castree, N. The anthropocene and the environmental humanities: Extending the conversation. Environ. Humanit. 2014, 5, 233-260. [CrossRef]

4. Zalasiewicz, J.; Williams, M.; Haywood, A.; Ellis, E. The anthropocene: A new epoch of geological time. Philos. Trans. R. Soc. A 2011, 369, 835-841. [CrossRef] [PubMed]

5. Erlich, P.; Erlich, A. Can a collapse of global civilization be avoided. Proc. R. Soc. B 2013, 280, 1-9. [CrossRef]

6. Grumbach, S.; Hamant, O. Digital revolution or anthropocenic feedback? Anthr. Rev. 2018, 5, 87-96. [CrossRef]

7. Lade, S.; Steffen, W.; de Vries, W.; Carpenter, S.; Donges, J.; Gerten, D.; Hoff, H.; Newbold, T.; Richardson, K.; Rockström, J. Human impacts on planetary boundaries amplified by Earth system interactions. Nat. Sustain. 2020, 3, 119-128. [CrossRef]

8. Calvo, P. The ethics of Smart City (EoSC): Moral implications of hyperconnectivity, algorithmization and the datafication of urban digital society. Ethics Inf. Technol. 2020, 22, 141-149. [CrossRef]

9. Anttiroiko, A. Castells network concept and its connections to social, economic and political network analyses. J. Soc. Struct. 2015, 16, 1-18. [CrossRef]

10. Surugiu, M.-R.; Surugiu, C. International trade, globalization and economic interdependence between european countries: Implications for businesses and marketing framework. Procedia Econ. Financ. 2015, 32, 131-138. [CrossRef]

11. Popkova, E.; Bogoviz, A.V.; Sergi, B.S. Towards digital society management and 'capitalism $4.0^{\prime}$ in contemporary Russia. Humanit. Soc. Sci. Commun. 2021, 8, 77. [CrossRef]

12. Herrfahrdt-Pähle, E.; Schlüter, M.; Olsson, P.; Folke, C.; Gelcich, S.; Pahl-Wostl, C. Sustainability transformations: Socio-political shocks as opportunities for governance transitions. Glob. Environ. Chang. 2020, 63, 102097. [CrossRef] [PubMed]

13. Görg, C.; Plank, C.; Wiedenhofer, D.; Mayer, A.; Pichler, M.; Schaffartzik, A.; Krausmann, F. Scrutinizing the Great Acceleration: The Anthropocene and its analytic challenges for social-ecological transformations. Anthr. Rev. 2020, 7, 42-61. [CrossRef]

14. Ceballos, G.; García, A.; Ehrlich, P. The sixth extinction crisis loss of animal populations and species. J. Cosmol. 2010, 8, 1821-1831.

15. Martin, J.-L.; Maris, V.; Simberloff, D. The need to respect nature and its limits challenges society and conservation science. Proc. Natl. Acad. Sci. USA 2016, 113, 6105-6112. [CrossRef]

16. Collins, A.; Galli, A.; Hipwood, T.; Murthy, A. Living within a One Planet reality: The contribution of personal Footprint calculator. Environ. Res. Lett. 2020, 15, 1-14. [CrossRef]

17. IPCC. Summary for Policymakers-Global Warming of $1.5^{\circ} \mathrm{C}$. In Global Warming of $1.5^{\circ} \mathrm{C}$. An IPCC Special Report on the Impacts of Global Warming of $1.5^{\circ} \mathrm{C}$ above Pre-Industrial Levels and Related Global Greenhouse Gas Emission Pathways, in the Context of Strengthening the Global Response to the Threat of Climate Change; Masson-Delmotte, V., Zhai, P., Pörtner, H.-O., Roberts, D., Skea, J., Shukla, P.R., Pirani, A., Moufouma-Okia, W., Péan, C., Pidcock, R., et al., Eds.; Sustainable Development, and Efforts to Eradicate Poverty: Geneva, Switzerland, 2018; p. 32. 
18. Hegerl, G.; Luterbacher, J.; Gonzalez-Rouco, F.; Tett, S.F.B.; Crowley, T.; Xoplaki, E. Influence of human and natural forcing on European seasonal temperatures. Nat. Geosci. 2011, 4, 99-103.

19. Schurer, A.P.; Tett, S.F.B.; Hegerl, G. Small influence of solar variability on climate over the past millennium. Nat. Geosci. 2014, 7, 104-108. [CrossRef]

20. Abram, N.; McGregor, H.; Tierney, J.; Evans, M.; McKay, N.; Kaufman, D. The PAGES 2k Consortium. Early onset of industrial-era warming across the oceans and continents. Nature 2016, 536, 411-418. [CrossRef]

21. Koch, A.; Brierley, C.; Maslin, M.M.; Lewis, S.L. Earth system impacts of the European arrival and great dying in the Americas after 1492. Quat. Sci. Rev. 2019, 207, 13-36. [CrossRef]

22. Hegerl, G.; Brönnimann, S.; Cowan, T.; Friedman, A.; Hawkins, E.; Iles, C.; Muller, W.; Schurer, A.; Undorf, S. Causes of climate change over the historical record. Environ. Res. Lett. 2019, 14, 123006. [CrossRef]

23. Pavone, I.R. The Paris Agreement and the Trump administration: Road to now here. J. Int. Stud. 2018, 11, 34-49. [CrossRef]

24. Selby, J. The Trump presidency, climate change, and the prospect of a disorderly energy Transition. Rev. Int. Stud. 2019, 45, 471-490. [CrossRef]

25. Kedia, S. Approaches to low carbon development in China and India. Adv. Clim. Chang. Res. 2016, 7, 213-221. [CrossRef]

26. Zhang, Z.X. Making the Transition to a low-carbon economy: The key challenges for China. Asia Pac. Policy Stud. 2016, 3, 187-202. [CrossRef]

27. Robinson, W. Global capitalism theory and the emergence of transnational elites. Crit. Sociol. 2012, 38, 349-363. [CrossRef]

28. de la Barra, X. The global social uprising: Limits to predatory capitalism. Crit. Sociol. 2012, 38, 395-399. [CrossRef]

29. Igwe, I. History of the International Economy: The Bretton Woods System and its Impact on the Economic Development of Developing Countries. Athens J. Law 2018, 4, 105-126. [CrossRef]

30. Chornyy, O. Influence of the Bretton Woods institutions on economic growth: Literature survey for transitional economic systems. Econ. Sociol. 2011, 4, 32-41. [CrossRef] [PubMed]

31. Umeonyirioha, E. The Bretton Woods International Financial Institutions: Perspective of the Underdeveloped States. World J. Soc. Sci. Humanit. 2020, 6, 15-21. [CrossRef]

32. Jackson, R.B.; Friedlingstein, P.; Andrew, R.M.; Canadell, J.G.; Le Quéré, C.; Peters, G.P. Persistent fossil fuel growth threatens the Paris Agreement and planetary health. Environ. Res. Lett. 2019, 14, 1-8. [CrossRef]

33. Tollefson, J. Can Joe Biden make good on his ambitious climate agenda? Nature 2020, 588, 206-207. [CrossRef]

34. Lui, S.; Kuramochi, T.; Smit, S.; Roelfsema, M.; Hsu, A.; Weinfurter, A.; Chan, S.; Hale, T.; Fekete, H.; Lütkehermöller, K.; et al. Correcting course: The emission reduction potential of international cooperative initiatives. Clim. Policy 2021, 21, 232-250. [CrossRef]

35. Binsted, M.; Iyer, G.; Edmonds, J.; Vogt-Schilb, A.; Arguello, R.; Cadena, A.; Delgado, R.; Feijoo, F.; Lucena, A.F.P.; McJeon, H.; et al. Stranded asset implications of the Paris Agreement in Latin America and the Caribbean. Environ. Res. Lett. 2020, 15, 044026. [CrossRef]

36. Harris, N.L.; Gibbs, D.A.; Baccini, A.; Birdsey, R.A.; De Bruin, S.; Farina, M.; Fatoyinbo, L.; Hansen, M.C.; Herold, M.; Houghton, R.A.; et al. Global maps of twenty-first century forest carbon fluxes. Nat. Clim. Chang. 2021, 11, 234-240. [CrossRef]

37. Chuvieco, E.; Pettinari, M.L.; Koutsias, N.; Forkel, M.; Hantson, S.; Turco, M. Human and climate drivers of global biomass burning variability. Sci. Total Environ. 2021, 779, 146361. [CrossRef]

38. Brugger, H.; Eichhammer, W.; Mikova, N.; Donitz, E. Energy efficiency vision 2050: How will new societal trends influence energy future energy demand in the European countries. Energy Policy 2021, 152, 112216. [CrossRef]

39. Sovacool, B.K.; Demski, C.; Noel, L. Beyond climate, culture and confort in European preferences for low-carbon heat. Glob. Environ. Chang. 2021, 66, 102200. [CrossRef]

40. Pantucci, R. The many faces of China's belt and road initiative. Curr. Hist. 2021, 120, 28-34. [CrossRef]

41. Brakman, S.; Frankopan, P.; Garretsen, H.; Van Marrewijk, C. The New Silk Roads: An introduction to China's Belt and Road Initiative. Camb. J. Reg. Econ. Soc. 2019, 12, 3-16. [CrossRef]

42. Pieper, M. The linchpin of Eurasia: Kazakhstan and the Eurasian economic union between Russia's defensive regionalism and China's new Silk Roads. Int. Politics 2020. [CrossRef]

43. OECD. The Belt and Road Initiative in the Global Trade, Investment and Finance Landscape, in OECD Business and Finance Outlook 2018; OECD Publishing: Paris, France, 2018. [CrossRef]

44. Arora, S.; Bhaukhandi, K.D.; Mishra, P.K. Coronavirus lockdown helped the environment to bounce back. Sci. Total Environ. 2020, 742, 140573. [CrossRef] [PubMed]

45. Ali, S.M. China's Belt and Road: An Evolving Network. China's Belt Road Vis. Geoecon. Geopolit. 2020, 69-121. [CrossRef]

46. Blanchard, J.-M. Problematic Prognostications about China's Maritime Silk Road Initiative (MSRI): Lessons from Africa and the Middle East. J. Contemp. China 2020, 29, 159-174. [CrossRef]

47. Zhang, Y.; Zheng, X.; Cai, W.; Liu, Y.; Luo, H.; Guo, K.; Bu, C.; Li, J.; Wang, C. Key drivers of the rebound trend of China's CO 2 emissions. Environ. Res. Lett. 2020, 15, 104049. [CrossRef]

48. Union of Concerned Scientists. Global Warming Fact: More Than Half of All Industrial $\mathrm{CO}_{2}$ Pollution Has Been Emitted Since 1988. 2020. Available online: https:// blog.ucsusa.org/peter-frumhoff/global-warming-fact-co2-emissions-since-1988-764 (accessed on 2 July 2020). 
49. Peters, G.P.; Andrew, R.M.; Canadell, J.G.; Friedlingstein, P.; Jackson, R.B.; Korsbakken, J.I.; Le Quéré, C.; Peregon, A. Carbon dioxide emissions continue to grow amidst slowly emerging climate policies. Nat. Clim. Chang. 2020, 10, 3-6. [CrossRef]

50. Fieldman, G. Finance Unchained: The Political Economy of Unsustainability. Sustainability 2020, 12, 2545. [CrossRef]

51. Daggash, H.; Heuberger, C.; MacDowell, N. The role and value of negative emissions technologies in decarbonising the UK energy system. Int. J. Greenh. Gas Control 2019, 81, 181-198. [CrossRef]

52. Viola, L.A. US strategies of institutional adaptation in the face of hegemonic decline. Glob. Policy 2020, 11 (Suppl. S3), $28-39$. [CrossRef]

53. Dubash, N.K.; Khosla, R.; Rao, N.D.; Bhardwaj, A. India's energy and emissions future: An interpretive analysis of model scenarios. Environ. Res. Lett. 2018, 13, 074018. [CrossRef]

54. Moore, A. Anthropocene anthropology: Reconceptualizing contemporary global change. J. R. Anthropol. Inst. 2016, 22, 27-46. [CrossRef]

55. Crutzen, P. The Anthropocene. In Earth System Science in the Anthropocene; Ehlers, E., Krafft, T., Eds.; Springer: Berlin/Heidelberg, Germany, 2006.

56. Velders, G.; Andersen, S.; Daniel, J.; Fahey, D.; McFarland, M. The importance of the Montreal Protocol in protecting climate. Proc. Natl. Acad. Sci. USA 2007, 104, 4814-4819. [CrossRef] [PubMed]

57. Otto, I.; Wiedermann, M.; Cremades, R.; Donges, J.; Auer, C.; Lucht, W. Human agency in the Anthropocene. Ecol. Econ. 2020, 167, 106463. [CrossRef]

58. Long, N. Sociología del Desarrollo: Una Perspectiva Centrada en el Actor; COLSAN-CIESAS: San Luis Potosi, México, 2007.

59. Ceballos, G.; Ehrlich, P.; Dirzo, R. Population losses and the sixth mass extinction. Proc. Natl. Acad. Sci. USA 2017, 114, E6089-E6096. [CrossRef] [PubMed]

60. Wackernagel, M.; Williams, R. Our Ecological Footprint; New Society Publishers: Filadelfia, Paraguay, 1996.

61. Brand, U.; Görg, C.; Wissen, M. Overcoming neoliberal globalization: Social-ecological transformation from a Polanyian perspective and beyond. Globalizations 2020, 17, 161-176. [CrossRef]

62. NOAA. Earth System Research Laboratory: Trends in Atmospheric Carbon Dioxide. 2021. Available online: https://www.esrl. noaa.gov/gmd/ccgg/trends/gl_trend.html (accessed on 1 March 2021).

63. Lenzen, M.; Li, M.; Malik, A.; Pomponi, F.; Sun, Y.Y.; Wiedmann, T.; Faturay, F.; Fry, J.; Gallego, B.; Geschke, A.; et al. Global socio-economic losses and environmental gains from the coronavirus pandemic. PLoS ONE 2020, 15, e0235654. [CrossRef]

64. WHO. Coronavirus (COVID-19) Dashboard. 2021. Available online: https://covid19.who.int (accessed on 7 April 2021).

65. Lander, E.S.; Linton, L.M.; Birren, B.; Nusbaum, C.; Zody, M.C.; Baldwin, J.; Devon, K.; Dewar, K.; Doyle, M.; FitzHugh, W.; et al. Initial sequencing and analysis of the human genome. Nature 2001, 409, 860-921.

66. Comte, A. A General View of Positivism; Bridges, J.H., Translator; Routledge: London, UK, 1908.

67. Barouki, R.; Kogevinas, M.; Audouze, K.; Belesova, K.; Bergman, A.; Birnbaum, L.; Boekhold, S.; Denys, S.; Desseille, C.; Drakvik, E.; et al. The COVID-19 pandemic and global environmental change: Emerging research needs. Environ. Int. 2021, 146, 106272. [CrossRef]

68. Toledo, V. El metabolismo social: Una nueva teoría socioecológica. Relaciones 2013, 136, 41-71.

69. Fischer-Kowalski, M.; Krausmann, F.; Pallua, I. A sociometabolic reading of the Anthropocene: Modes of subsistence, population size and human impact on Earth. Anthr. Rev. 2014, 1, 8-33. [CrossRef]

70. Lenton, T.M.; Pichler, P.-P.; Weisz, H. Revolutions in energy input and material cycling Earth history and human history. Earth Syst. Dyn. 2016, 7, 353-370. [CrossRef]

71. Schaffer, L.M.; Spilker, G. Self-interest versus sociotropic considerations: An information-based perspective to understanding individuals' trade preferences. Rev. Int. Political Econ. 2019, 26, 1266-1292. [CrossRef]

72. Frantz, C.; Mayer, S.; Norton, C.; Rock, M. There is no "I" in nature: The influence of self-awareness on connectedness to nature. J. Environ. Psychol. 2005, 25, 427-436. [CrossRef]

73. Gifford, R. The dragons of inaction: Psychological barriers that limit climate change mitigation and adaptation. Am. Psychol. 2011, 66, 290-302. [CrossRef]

74. Komatsu, H.; Rappleye, J.; Silova, I. Culture and the independent self: Obstacles to environmental sustainability. Anthropocene 2019, 26, 100198. [CrossRef]

75. Paramio, L. Teorías de la decisión racional y de la acción colectiva. Sociológica 2005, 57, 13-34.

76. Miller, L.M. Acción colectiva y modelos de racionalidad. Estud. Front. 2004, 5, 107-130.

77. Lugo-Morin, D.R. La multi-racionalidad económica del pequeño productor en los territorios rurales. Span. J. Rural Dev. 2011, 2, 21-38. [CrossRef]

78. WMO. Global Atmosphere Watch Programme (GAW). 2020. Available online: https://community.wmo.int/activity-areas/gaw (accessed on 10 December 2020).

79. U.S. Energy Information Administration. Emisiones Totales de $\mathrm{CO}_{2}$ a Nivel Global 1980-2017. 2020. Available online: https: //www.eia.gov/international/data/world/other-statistics (accessed on 10 December 2020).

80. GEO5. Perspectivas del Medio Ambiente Mundial; Programa de las Naciones Unidas para el Medio Ambiente: Nairobi, Kenya, 2012.

81. Zalasiewicz, J.; Waters, C.N.; Summerhayes, C.P.; Wolfe, A.P.; Barnosky, A.D.; Cearreta, A.; Crutzen, P.; Ellis, E.; Fairchild, I.J.; Gałuszka, A.; et al. The Working Group on the Anthropocene: Summary of evidence and interim recommendations. Anthropocene 2017, 19, 55-60. [CrossRef] 
82. Lewis, S.; Maslin, M. Defining the Anthropocene. Nature 2015, 519, 171-180. [CrossRef]

83. Gillings, M.; Paulsen, I. Microbiology of the Anthropocene. Anthropocene 2014, 5, 1-8. [CrossRef]

84. Brondizio, E.; O’Brien, K.; Bai, X.; Biermann, F.; Steffen, W.; Berkhout, F.; Cudennec, C.; Lemos, M.; Wolfe, A.; Palma-Oliveira, J.; et al. Re-conceptualizing the Anthropocene: A call for collaboration. Glob. Environ. Chang. 2016, 39, 318-327. [CrossRef]

85. Hmiel, B.; Petrenko, V.V.; Dyonisius, M.N.; Buizert, C.; Smith, A.M.; Place, P.F.; Harth, C.; Beaudette, R.; Hua, Q.; Yang, B.; et al. Preindustrial 14CH4 indicates greater anthropogenic fossil CH4 emissions. Nature 2020, 578, 409-412. [CrossRef]

86. Turetsky, M.; Abbott, B.; Jones, M.; Anthony, K.; Olefeldt, D.; Schuur, E.; Koven, C.; McGuire, D.; Grosse, G.; Kuhry, P.; et al. Permafrost collapse is accelerating carbon release. Nature 2019, 569, 32-34. [CrossRef] [PubMed]

87. Yuewen, D.; Adzigbli, L. Assessing the impact of oil spills on marine organisms. J. Oceanogr. Mar. Res. 2017, 6, 1-7. [CrossRef]

88. Qing, Q.L.; Loganath, A.; Chong, Y.; Tan, J.; Philip, J. Persistent Organic Pollutants and Adverse Health Effects in Humans. J. Toxicol. Environ. Health 2006, 69, 1987-2000. [CrossRef]

89. Konikow, L.; Kendy, E. Groundwater depletion: A global problem. Hydrogeol. J. 2005, 13, 317-320. [CrossRef]

90. Kassas, M. The biosphere and the threat of global industrialisation: Limits of the biosphere. Environmentalist 1989, 9, $261-268$. [CrossRef]

91. Cowgill, U. Acid precipitation: A review. Stud. Environ. Sci. 1984, 35, 233-259.

92. Duguma, L.; Atela, J.; Minang, P.; Ayana, A.; Gizachew, B.; Nzyoka, J.; Bernard, F. Deforestation and Forest Degradation as an Environmental Behavior: Unpacking Realities Shaping Community Actions. Land 2019, 8, 26. [CrossRef]

93. Carvalho, F. Pesticides, environment and food safety. Food Energy Secur. 2017, 6, 48-60. [CrossRef]

94. Baisero, D.; Visconti, P.; Pacifici, M.; Cimatti, M.; Rondinini, C. Projected Global Loss of Mammal Habitat Due to Land-Use and Climate Change. One Earth 2020, 2, 578-585. [CrossRef]

95. Reyes-Garcia, V.; Gueze, M.; Luz, A.; Paneque-Gálvez, J.; Macía, M.; Orta-Martinez, M.; Pino, J.; Rubio-Campillo, X. Evidence of Traditional Knowledge Loss among a Contemporary Indigenous Society. Evol. Hum. Behav. 2013, 34, 249-257. [CrossRef]

96. Hrubec, M.; Uhde, Z. Global Conflicts and Local Interactions: Contradictions of Global Capitalism and Civil Society. Crit. Sociol. 2018, 45, 1-7. [CrossRef]

97. Martins, F.; Felgueiras, C.; Smitkova, M.; Caetano, N. Analysis of Fossil Fuel Energy Consumption and Environmental Impacts in European Countries. Energies 2019, 12, 964. [CrossRef]

98. Lambin, E.; Geist, H.; Lepers, E. Dynamics of Land-use and land-cover change in tropical regions. Annu. Rev. Environ. Resour. 2002, 20, 205-241.

99. Babic, M. Let's talk about the interregnum: Gramsci and the crisis of the liberal world order. Int. Aff. 2020, 96, 767-786. [CrossRef]

100. Bai, X.; van der Leeuw, S.; O’Brien, K.; Berkhout, F.; Biermann, F.; Brondizio, E.; Cudennec, C.; Dearing, J.; Duraiappah, A.; Glaser, M.; et al. Plausible and desirable futures in the Anthropocene: A new research agenda. Glob. Environ. Chang. 2016, 39, 351-362. [CrossRef]

101. Bonneuil, C. The geological turn: Narratives of the Anthropocene. In The Anthropocene and the Global Environmental Crisis: Rethinking Modernity in a New Epoch; Hamilton, C., Bonneuil, C., Gemenne, C.F., Eds.; Routledge: London, UK, 2015 ; pp. 15-31.

102. Danowski, D.; Viveiros de Castro, E. Los miedos y los fines ... del mundo. Rev. Nueva Soc. 2019, 283, 37-46.

103. Latour, B. Telling friends from foes in the time of the Anthropocene. In The Anthropocene and the Global Environmental Crisis: Rethinking Modernity in a New Epoch; Hamilton, C., Bonneuil, C., Gemenne, C.F., Eds.; Routledge: London, UK, 2015 ; pp. 145-155.

104. Descola, P. Beyond Culture and Nature. J. Ethnogr. Theory 2012, 2, 447-471. [CrossRef]

105. Hornborg, A.; McNeill, J.; Martinez-Alier, J. Rethinking Environmental History: World-System History and Global Environmental Change; Altamira Press: Lanham, MD, USA, 2007.

106. Tainter, J. Archaeology of overshoot and collapse. Annu. Rev. Anthropol. 2006, 35, 59-74. [CrossRef]

107. Diamond, J. Collapse: How Societies Choose to Fail or Succeed; Viking Penguin: New York, NY, USA, 2005.

108. Meadows, D.; Meadows, D.; Randers, J.; Behrens, W. The Limits to Growth; Universe Books: New York, NY, USA, 1972.

109. Marx, K.; El Capital, T. Libro Primero, El Proceso de Producción del Capital; Siglo XXI: México City, México, $1975 ;$ Volume 2.

110. Brzezinski, M. Income Polarization and Economic Growth; National Bank of Poland Working Paper No. 147; SSRN: Rochester, NY, USA, 2013. [CrossRef]

111. Roope, L.; Niño-Zarazúa, M.; Tarp, F. How polarized is the global income distribution? Econ. Lett. 2018, 167, 86-89. [CrossRef]

112. Habets, I. Democracia liberal: La amenaza de las contranarrativas. Eur. View 2015, 14, 145-154. [CrossRef]

113. Becker, J.; Raza, W. Theory of regulation and political ecology an inevitable separation. Ambiente Soc. 1999, 5, 5-17. [CrossRef]

114. van der Leeuw, S.; Folke, C. The social dynamics of basins of attraction. Ecol. Soc. 2021, 26, 33. [CrossRef]

115. IPCC. The Physical Science Basis. In Contribution of Working Group I to the Fourth Assessment Report of the Intergovernmental Panel on Climate Change; Cambridge University Press: Cambridge, UK, 2007.

116. Keller, D.; Lenton, A.; Littleton, E.; Oschlies, A.; Scott, V.; Vaughan, N. The Effects of Carbon Dioxide Removal on the Carbon Cycle. Curr. Clim. Chang. Rep. 2018, 4, 250-265. [CrossRef]

117. Tol, R. The structure of the climate debate. Energy Policy 2017, 104, 431-438. [CrossRef]

118. Duijndam, S.; van Beukering, P. Understanding public concern about climate change in Europe, 2008-2017: The influence of economic factors and right-wing populism. Clim. Policy 2021, 21, 353-367. [CrossRef]

119. van Beek, L.; Hajer, M.; Pelzer, P.; van Vuuren, D.; Cassen, C. Anticipating futures through models: The rise of integrated assessment modelling in the climate science-policy interface since 1970. Glob. Environ. Chang. 2020, 65, 102191. [CrossRef] 
120. Zakkour, P.D.; Heidug, W.; Howard, A.; Haszeldine, R.S.; Allen, M.R.; Hone, D. Progressive supply-side policy under the Paris Agreement to enhance geological carbon storage. Clim. Policy 2021, 21, 63-77. [CrossRef]

121. Tortell, P. Earth 2020: Science, society, and sustainability in the Anthropocene. Proc. Natl. Acad. Sci. USA 2020, $117,8683-8691$. [CrossRef] [PubMed]

122. Molina, M.; Rowland, S. Stratospheric sink for chlorofluoromethanes: Chlorine atom-catalysed destruction of ozone. Nature 1974, 249, 810-812. [CrossRef]

123. Kannan, K.; Tanabe, S.; Giesy, J.; Tatsukawa, R. Organochlorine pesticides and polychlorinated biphenyls in foodstuffs from Asian and oceanic countries. Rev. Environ. Contam. Toxicol. 1997, 152, 1-55. [PubMed]

124. Steinbacher, M.; Vollmer, M.K.; Buchmann, B.; Reimann, S. An evaluation of the current radiative forcing benefit of the Montreal Protocol at the high-Alpine site Jungfraujoch. Sci. Total Environ. 2008, 391, 217-223. [CrossRef]

125. Kanter, D.; Mauzerall, D.; Ravishankara, A.R.; Daniel, J.; Portmann, R.; Grabiel, P.; Moomaw, W.; Galloway, J. A post-Kyoto partner: Considering the stratospheric ozone regime as a tool to manage nitrous oxide. Proc. Natl. Acad. Sci. USA 2013, 110, 4451-4457. [CrossRef]

126. Ghani, G. The Montreal Protocol: Developing Countries Import of Halons. Econ. Bull. 2007, 17, 1-5.

127. Ivanova, K. Corruption, illegal trade and compliance with the Montreal Protocol. Environ. Resour. Econ. 2007, 38, 475-496. [CrossRef]

128. Stone, C. Common but Differentiated Responsibilities in International Law. Am. J. Int. Law 2004, 98, 276-301. [CrossRef]

129. Jotzo, F. Developing countries and the future of the kyoto protocol. Glob. Chang. Peace Secur. 2005, 17, 77-86. [CrossRef]

130. Keenan, T.; Prentice, C.; Canadell, J.; Williams, C.; Wang, H.; Raupach, M.; Collatz, J. Recent pause in the growth rate of atmospheric $\mathrm{CO}_{2}$ due to enhanced terrestrial carbon uptake. Nat. Commun. 2017, 8, 1-10. [CrossRef]

131. Zahnle, K.; Schaefer, L.; Fegley, B. Earth's Earliest Atmospheres. Cold Spring Harb. Perspect. Biol. 2010, 2, a004895. [CrossRef]

132. Hart, M. The evolution of the atmosphere of the Earth. Icarus 1978, 33, 23-39. [CrossRef]

133. Oschmann, W.; Grasshoff, M.; Gudo, M. The early evolution of the planet earth and the origin of life. Senckenbergiana Lethaea 2002, 82, 284-294. [CrossRef]

134. Pearce, B.; Tupper, A.; Pudritz, R.; Higgs, P. Constraining the Time Interval for the Origin of Life on Earth. Astrobiology 2018, 18, 343-364. [CrossRef] [PubMed]

135. Shaw, G. Earth's atmosphere-Hadean to early Proterozoic. Chem. Der Erde-Geochem. 2008, 68, 235-264. [CrossRef]

136. Abe, Y.; Matsui, T. Early Evolution of the Earth: Accretion, Atmosphere Formation, and Thermal History. J. Geophys. Res. 1986, 91, E291-E302. [CrossRef]

137. Zahnle, K.; Kasting, J.; Pollack, J. Evolution of a steam atmosphere during Earth's accretion. Icarus 1988, 74, 62-97. [CrossRef]

138. Genda, H. Origin of Earth's oceans: An assessment of the total amount, history and supply of water. Geochem. J. 2016, 50, 27-42. [CrossRef]

139. Sorokhtin, O.; Ghilingar, G.; Khlyuk, L.; Gorfunkel, M. Evolution of the Earth's Global Climate. Energy Sources Part A 2007, 29, 1-19. [CrossRef]

140. Sofia, D.; Gioiella, F.; Lotrecchiano, N.; Giuliano, A. Cost-benefit analysis to support decarbonization scenario for 2030: A case study in Italy. Energy Policy 2020, 137, 111137. [CrossRef]

141. Leiss, W. A global decarbonisation bond. Environ. Res. Lett. 2019, 14, 091003. [CrossRef]

142. Pye, S.; Broad, O.; Bataille, C.; Brockway, P.; Daly, H.; Freeman, R.; Gambhir, A.; Geden, O.; Rogan, F.; Sanghvi, S.; et al. Modelling net-zero emissions energy systems requires a change in approach. Clim. Policy 2021, 21, 222-231. [CrossRef]

143. Rueda, O.; Mogollón, J.M.; Tukker, A.; Scherer, L. Negative-emissions technology portfolios to meet the $1.5^{\circ} \mathrm{C}$ target. Glob. Environ. Chang. 2021, 67, 102238. [CrossRef]

144. Millward-Hopkins, J.; Steinberger, J.; Rao, N.D.; Oswald, Y. Providing decent living with minimum energy: A global scenario. Glob. Environ. Chang. 2020, 65, 102168. [CrossRef] 